Katarzyna Szkaradnik

Uniwersytet Śląski (Katowice)

\title{
„Pozostał tylko pusty cokół - / ślad dłoni szukający kształtu" (Z. Herbert, Do Apollina). Hermeneutyka wobec współczesnej „słabej obecności” mitów
}

Na truizm zakrawa stwierdzenie, że obecnie trudno nawiązywać do antycznych mitów na zasadzie naiwnej rewokacji czy ornamentyki. Wprawdzie nawet pozornie proste przywołania - z uwagi na nowy kontekst historyczny - inicjują dialog z pierwowzorem, ale najczęściej motywy z mitologii podejmowane są ironicznie ${ }^{1}$, co poniekąd koresponduje $\mathrm{z}$ krachem wiary w kosmiczną harmonię w rezultacie rozpoznań tak zwanych mistrzów podejrzeń, grozy Shoah oraz generalnego „odczarowania świata”. Niemniej mity pozostają intrygującą domeną inspiracji, również od połowy XX wieku do dziś - takimi ramami ograniczę „współczesność”, a z powodu bogactwa problematyki przyjrzę się przejawom mitów grecko-rzymskich $\mathrm{w}$ poezji polskiej. Także w jej obrębie napotkać można ogrom sposobów i funkcji ewokowania owych motywów, lecz chodzić tu będzie o pewną ogólną perspektywę - oczywiście jedną z wielu potencjalnych.

Rzeczoną propozycję teoretyczno-interpretacyjną upatruję w hermeneutyce radykalnej, którą od tradycyjnej odróżniałby nacisk na tytułową „słabość”. Nie oznacza ona rzadkości odniesień do mitów, ale określa ich charakter, związany z sytuacją myśli europejskiej - upadkiem „mocnych”, totalizujących struktur metafizycznych (prymatu kategorii rozumu, substancji, bytu przeciwstawionego pozorowi). Promowana przez Gianniego Vattima „myśl słaba” stanowi zatem analogon bycia słabego - wycofującego się i stającego się, tzn. pozbawionego esencji, co mówi nie tyle o jego

1 Zob. S. Stabryła, Antyk we wspótczesnej literaturze polskiej, Wrocław 1980, s. 7-8. 
„naturze”, ile o jego historycznym obliczu. Na zmienny sens bycia odpowiada nie prawda wieczna, lecz prawda dziejowości egzystencji², będąca „umiejscowionym w historii i skończonym «wrzuceniem», (...) pochodzeniem warunków możliwości doświadczenia”3. Medium różnych sfer doświadczenia okazuje się samo bycie, pojęte jako wydarzanie się: nie to, co „obecne”, tylko wieść z przeszłości zapośredniczona w licznych śladach, znakach, przekazach. Bycie ma więc charakter językowy, interpretacyjny, wydaje się „pozbawione początku, niejasne, zagubione w micie”4. Bezpośrednio kwestię mitów Vattimo porusza w książce Społeczeństwo przejrzyste, gdzie wśród aprobatywnych podejść do mitów wyróżnia, po pierwsze, utopijny archaizm, płynący z przeświadczenia o nieautentyczności cywilizacji Zachodu (mity, czytane na nowo, mają nas wyzwolić od błędów nowoczesności); po drugie, relatywizm kulturowy, negujący uniwersalną racjonalność i opozycję mit - nauka; po trzecie, umiarkowany irracjonalizm, uważający strukturę mitu za adekwatną do pewnych obszarów doświadczenia (nieświadomość, mass media). Wszystkie trzy nie unikają aporii, gdyż pomijają kontekst własnego powstania, czyli zmianę w postrzeganiu metafizycznej tradycji ${ }^{5}$.

Stosunek do tej tradycji postulowany przez Vattima zdaje się pokrewny stosunkowi części poetów do tematyki mitycznej jako jej elementu. Autor Końca nowoczesności nawołuje do przemyślenia metafizyki przez pryzmat Heideggerowskiego pojęcia Verwindung - oznacza ono uwolnienie się, rekonwalescencję, ale też

${ }^{2}$ Zob. M. Szulakiewicz, Filozofia jako hermeneutyka, Toruń 2004, s. 123.

${ }^{3}$ G. Vattimo, Poza interpretacja. Znaczenie hermeneutyki dla filozofii, red. A. Kuczyńska, przeł. K. Kasia, Kraków 2011, s. 26.

${ }^{4}$ G. Vattimo, P. Paterlini, Nie być Bogiem. Autobiografia na cztery rece, przeł. K. Kasia, Warszawa 2011, s. 101-102.

${ }^{5}$ Skoro upadł „mit” emancypacji rozumu i „demityzacja okazuje się mitem, mit odzyskuje swą prawowitość, lecz tylko w kontekście ogólnego «osłabienia» doświadczenia prawdy” - G. Vattimo, Społeczeństwo przejrzyste, przeł. M. Kamińska, Wrocław 2006, s. 54. 
akceptację i pogłębienie ${ }^{6}$. Celem nie byłoby więc odrzucenie dziedzictwa metafizyki (bez niego nie może się obyć europejska refleksja); raczej, mając świadomość jego przygodności, trzeba je podjąć przez przebolenie i zniekształcenie (tak również Włoch tłumaczy Verwindung) ${ }^{7}$. Pożegnanie splata się tutaj z kontynuacją, gdyż jesteśmy uwikłani w dzieje bycia i namysłu nad nim, toteż pozostaje nam świadomość, że „musimy śnić”, oraz interpretacja podtrzymująca, a zarazem „rozrzedzająca” tradycję ${ }^{8}$. Taka hermeneutyka miałaby za patrona nie Hermesa - skrupulatnego pośrednika, lecz przekornego wędrowca, który uosabia przejście, niedookreślenie, kontakt z innym ${ }^{9}$. Tego boga Jacek Łukasiewicz uznaje za najbliższego Zbigniewowi Herbertowi: „Jest sprytny, ironiczny, a jednocześnie wierny Olimpowi, któremu służy i do którego należy, wierny więc mitologii" ${ }^{10}$.

Postawe Verwindung można przypisać także innym twórcom sięgającym do mitów jako residuum formuł wypowiadania doświadczenia i szukającym analogii nawet dla (na pozór?) bezprecedensowych wydarzeń XX wieku. Wskutek tego Odys stał się wręcz uosobieniem modelowego życiorysu epoki, Warszawa nową Troją, a polityczny aspekt mitologicznych apokryfów Herberta odczytywany jest nie uniwersalnie, lecz aktualnie. Taka lektura konweniuje z rozumieniem przez Vattima bycia jako językowej praktyki, którą:

podmiot egzystujący w konkretnej konfiguracji historyczno-kulturowej interpretuje (...) za pomocą kategorii wypracowanych przez rzeczoną konfigurację. Zadaniem podmiotu $\mathrm{w}$ ponowoczesności nie jest zatem

${ }^{6}$ Zob. idem, Postnowoczesność i kres historii, przeł. B. Stelmaszczyk, [w:] Postmodernizm. Antologia przekładów, wybór i oprac. R. Nycz, Kraków 1997, s. 133-134.

7 Zob. idem, Nihilizm i postmodernizm w filozofii, [w:] idem, Koniec nowoczesności, przeł. M. Surma-Gawłowska, Kraków 2006, s. 160-165.

${ }^{8}$ Zob. idem, Społeczeństwo przejrzyste, op. cit., s. 52-53.

9 Zob. M. Szulakiewicz, Od transcendentalizmu do hermeneutyki, Rzeszów 1998, s. 233, 235.

10 J. Łukasiewicz, Herbert, Wrocław 2001, s. 126. 
uchwytywanie ontologicznych uniwersaliów, lecz hermeneutycznych śladów teraźniejszości ${ }^{11}$.

Co jednak z konwencjonalizacją i trywializacją motywów mitologicznych, owymi - jak ich nazywa Herbert w tytule cyklu z Króla mrówek - „bogami z zeszytów szkolnych”? W tym kontekście Jacek Bocheński porównuje topikę antyczną do muzeum figur woskowych $^{12}$, natomiast Jacek Brzozowski przekonuje, że:

\begin{abstract}
wyobrażenie antyku jako marmurowej bieli (...) nie stwarza nadziei na odnalezienie właśnie tam (...) ożywiającego źródła. Odrzucenie owego (...) parnasistowskiego obrazu Hellady i Romy (...) [jest jednak] tylko przekreśleniem (...) grubej warstwy farb nakładanych przez pokolenia na dom, który był ich pierwszym domem, rodzinnym ${ }^{13}$.
\end{abstract}

Niewykonalne zdaje się więc „odwołanie mitu” (tytuł tomu Anny Kamieńskiej), czego wyrazem jest nobilitacja mitów w badaniach kultury (vide Cassirer czy Eliade), z kolei w literaturze zaufanie do zawartych w nich archetypów przejawia się w mityzacji (kreacji „archaicznego” świata sensu, arkadii) w opozycji do mitologizacji (reinterpretacji) ${ }^{14}$. Dosyć słusznie już Przyboś zarzucał pierwszej „mitomanię”, nieautentyczność: „Co zdanie, co wierszyk, straszy jakiś archetyp lub wysterka antropologiczna strukturka"15.

Zazwyczaj jednak przymiarka mitologii do współczesności wypada na niekorzyść tej drugiej, uwypukla nieprzystawalność klasycznej harmonii do dwudziestowiecznych traum i „banalności zła” - stąd konstatacje, że tragedia stała się już niemożliwa.

${ }^{11}$ M. Wróblewski, Zatarg Jeana-Françoisa Lyotarda, czyli o postmodernizmie raz jeszcze, „Diametros” 2010, nr 24, s. 133.

12 Zob. J. Bocheński, Przywitanie konferencji, [w:] Topika antyczna w literaturze polskiej XX wieku. Studia, red. A. Brodzka, E. Sarnowska-Temeriusz, Wrocław 1992, s. 11-12.

13 J. Brzozowski, Antyk Herberta, [w:] Topika antyczna..., s. 91.

${ }^{14}$ Zob. np. T. Mizerkiewicz, Mitologizacje. O zwiazkach intertekstualnych z mitologia w powieści polskiej po 1956 roku, „Pamiętnik Literacki” 2000, z. 4, s. 83.

15 J. Przyboś, Zapiski bez daty, Warszawa 1970, s. 198. 
Aleksander Wat w Biografii kreśli życiorys analogiczny do Edypowego, osadzony w groteskowych realiach ZSRR. Przewrotna puenta ukazuje zastąpienie heroicznej walki z fatum przez rzekomą „konieczność dziejową”: „I nikt nie zazna żadnego katharsis. Przecież / nieubłagana jest dialektyka towarzyszki Ananke"16.

Również Ernest Bryll w Rekonstrukcji chóru Sofoklesowego kwestionuje możliwość wielkości na miarę Edypa: „bóg otrząsnął swe palce i schodzisz ze sceny, / mały jak resztka brudu. Nawet nie przeklęty"17. W sarkastycznym Sukcesie Piotra Fluksa osiagnięciem współczesnych jest uświadomienie sobie, do czego służyła konstrukcja Dedala - do „zniszczenia człowieka” - jednak o ile tamtą cechował pewien kunszt, o tyle dziś rządzi ,prostota i efektywność”, a z klimatu mitologii pozostał tylko „smród odchodów Minotaura"18.

Niemniej zwykle taka konfrontacja ma cel etyczny: demaskuje raczej obecną epokę niż mity, co również pokazuje, że od ich perspektywy nie sposób uciec, że choćby jako negatyw są horyzontem doświadczenia, dziedzictwem ulegającym reinterpretacji, czyli deformowaniu (Verwindung) i - przekazywaniu dalej. Jak podkreśla Vattimo, „myśl słaba” akcentuje różnicę, która nie prowadzi do „powtarzania zawsze równych sobie struktur, lecz rozwija się jako (...) historycznie określona rozbieżność pomiędzy horyzontem de-terminującym pewną epokę (...) a tym, co wewnątrz niej jawi się jako obecne" ${ }^{19}$. Na ową dialektykę w przypadku Herberta wskazuje Stanisław Barańczak, diagnozując u autora Studium przedmiotu rozdarcie między wydziedziczeniem $\mathrm{z}$ antycznej schedy a pamięcią

${ }^{16}$ A. Wat, Biografia, [w:] idem, Wybór wierszy, oprac. A. Dziadek, Wrocław 2008, s. 246.

${ }^{17}$ E. Bryll, Rekonstrukcja chóru Sofoklesowego, [w:] idem, Wiersze wybrane, Kraków 1978, s. 42.

18 P. Fluks, Sukces, [w:] Po Wojaczku. Antologia poezji polskiej 1971-1991, red. K. Ratyniecki, Warszawa 1991, s. 64.

${ }^{19}$ G. Vattimo, Le avventure della differenza, cyt. za: A. Zawadzki, Literatura a myśl słaba, Kraków 2009, s. 95. 
o niej jako odniesieniu dla wartości ${ }^{20}$ - o tradycji rozbitej i rozproszonej niczym bycie w ujęciu Vattima ${ }^{21}$.

Podobnie jak metafizyka, mity nie są już stabilnym modelem wyjaśniania, ale nieprzejrzystymi opowieściami o byciu, które potwierdzają naszą przeszłość i wyzwalają ją w formie narracji. Nie przypadkiem użyłam słowa „wyzwalaja”, tak bowiem - jako uwalnianie - rozumiałabym „rozwiązywanie mitologii”, jeśli za Małgorzatą Mikołajczak przypisać je Herbertowi ${ }^{22}$. Nie utożsamiłabym zaś tego z „rozszyfrowywaniem tajemnicy”, konotującym istnienie „mocnego” sensu. Tymczasem chodzi o reinterpretowanie, w czym autor Napisu przypomina poetów hellenistycznych, którzy, nawiązując do mitów, interesowali się ich sprzecznymi wariantami i wyzyskiwali napięcia między nimi ${ }^{23}$.

Mity kolidujące z sobą, rozsypane, niczym bycie przesyłają się i podlegają „upływowi”24. Vattimo odnosi się do przygodności bycia i śladowości kulturowych przesłań, proponując postawę pietas $^{25}$ - pobożnej troski o owe szczątki jako swoiste pamiątki. Nawet kategorie metafizyki pozostają „monumentami”, znakami istot uwikłanych w czas i ich zmagań z własną dziejowością ${ }^{26}$ oraz

${ }^{20}$ Zob. S. Barańczak, Uciekinier z Utopii. O poezji Zbigniewa Herberta, Warszawa 2001, s. 57-64.

${ }^{21}$ Dla porządku warto wspomnieć o odmiennej lekturze Herberta, jaką proponuje Józef Maria Ruszar. Dowartościowując rolę spuścizny rzymskiego antyku u poety, badacz analizuje obraz Rzymu jako sui generis mit, a zarazem wciąż żywy paradygmat europejskiej cywilizacji, przy czym istotne jest jej dwojakie oblicze: kruchość i trwałość, poskramianie barbarzyństwa i podszycie zbrodnią. Zob. np. J.M. Ruszar, Słońce republiki. Cywilizacja rzymska w twórczości Zbigniewa Herberta, Kraków 2014, s. 19-27.

${ }^{22}$ Zob. M. Mikołajczak, „W cieniu heksametru”. Interpretacje wierszy Zbigniewa Herberta, Zielona Góra 2004, s. 106.

${ }^{23}$ Zob. [Lektor], Mit i współczucie, „Tygodnik Powszechny” 2008, nr 22, s. 30.

${ }^{24}$ Zob. J. Caputo, Radical Hermeneutics. Repetition, Deconstruction and the Hermeneutic Project, Bloomington-Indianapolis 1987, passim.

${ }_{25}$ Zob. G. Vattimo, Dialektyka, różnica, myśl słaba, przeł. M. Surma, A. Zawadzki, ,Teksty Drugie” 2003, nr 5, s. 131-132.

${ }^{26}$ Zob. idem, Postnowoczesność i kres historii, op. cit., s. 137. 
wzbogaceniem naszego doświadczenia. Za Heideggerem Włoch mówi o Andenken: rozpamiętywaniu śladów z przeszłości jako czegoś drogiego, nie przeżytku. W ten sposób nierzadko poezja przywołuje mity - jako

dziedzinę znaczeń konstytuującą świat człowieka. (...) [Ich] demaskacja nie polegałaby na ściagganiu masek (...), lecz na kolekcjonowaniu ich ze świadomością, że (...) są jedyną rzeczywistością istniejącą i dostępną poznaniu ${ }^{27}$.

Nie byłby to estetyzm, ale imperatyw etyczny: Vattimo pisze o byciu osłabionym, zużytym, ułomność zaś jest warunkiem doświadczenia ${ }^{28}$, warunkiem wspólnoty człowieczeństwa, i winna skłaniać do współczucia.

W kontekście mitów jako szczątków warto rozwinąć Vattimowski trop „monumentu”, gdyż w znaczeniach „śladu” zachodzi dialektyka między ułomnością samego mitu i tego, co mu się wymyka. W U schyłku XX wieku Adama Czerniawskiego ${ }^{29}$ mit zagarnia opowieść o miłości i śmierci, lecz nie „zbitki kości” czy spojrzenie pełne strachu. Byłby więc petryfikacją i idealizacją, podczas gdy życie jest „podmuchem erozji”, wyrwą, śladem przejawiającym się jako brak.

Stąd bliższe dramatyzmowi egzystencji naznaczonej upływem wydają się posągi rozbite, kalekie - jak Nike z wiersza Ernesta Brylla, która utraciła swą funkcję, bo zniszczeniu uległ statek, na którego dziobie czuwała. Z niej samej pozostały ułomki, niemniej przechowała zarówno „echo krzyków”, jak i wyobrażenie „potu wioślarzy"30, dzięki czemu można dosnuć narrację o bitwie; łączy się tu ponadczasowe pragnienie sławy z egzystencjalnym konkretem. Co prawda wzmianki o chłodzie posągu, jałowości i Styksie

27 A. Zawadzki, op. cit., s. 74-75.

${ }^{28}$ G. Vattimo, Dialektyka, różnica, myśl słaba, op. cit., s. 132.

${ }^{29}$ Zob. A. Czerniawski, U schyłku XX wieku, [w:] idem, Poezje zebrane, Łódź 1993, s. 244-245.

${ }^{30}$ Zob. E. Bryll, Nike, [w:] idem, Wiersze wybrane, op. cit., s. 36. 
niepokoją, lecz zdegradowana bogini, „obmyta ziemią”, zaczyna dzielić z ludźmi ich dolę, a chociaż utkwiła w piachu, płyną poprzez nią echa przeszłości ${ }^{31}$. Podobny motyw zawiera Archeologia Kamieńskiej - podmiot kontempluje antyczne rzeźby w muzeum, by stwierdzić, że przetrwało z nich to, co najbardziej znikome: „Potężna bryła powietrza / Wsparta na jednej stopie / Ugrzęzłej w ziemskim piasku”32.

Na ową wagę ziemskości rzuca światło Heideggerowska opozycja otwartości świata oraz ziemi jako skrytości, otchłani bez logicznego „fundamentu” - między nimi oscyluje dzieło sztuki, które odsłania przygodność kulturowych porządków, „ogólną nieobecność racji i znaczeń”33. Dlatego problematyczna wydaje się siła niekompletnego posągu ze słynnego sonetu Rilkego Starożytny tors Apollina, w którym ubytek materii nie neguje pełni ducha, jaką emanuje rzeźba - z perspektywy hermeneutyki radykalnej wydaje się to zbyt łatwe.

Omawianą orientację należy także odróżnić od stanowiska Ryszarda Przybylskiego, który klasycyzm definiuje właśnie jako hermeneutykę, tzn. dochodzenie do wiedzy o człowieku przez „odszyfrowywanie dokumentów jego życia"34, tekstów kultury. Dla tego badacza jednak kultura dąży do wyższej harmonii, konflikty i dramaty niwelowane są w jej ,wiecznym teraz”, toteż de facto interpretacja okazuje się zbędna ${ }^{35}$. Tymczasem hermeneutyka radykalna uwypukla dziejowość i skończoność, a jej zadaniem nie

${ }^{31} \mathrm{Na}$ ten przepływ warto ukierunkować hermeneutyczną lekturę mitów, zwłaszcza że hermeneutyka radykalna „nie stara się już interpretować treści przekazywanej przez (...) dzieje, ale dziejące się przekazywanie” - N. Leśniewski, O hermeneutyce radykalnej, Poznań 1998, s. 162.

32 A. Kamieńska, Archeologia, [w:] eadem, Poezje wybrane, Warszawa 1973, s. 54.

33 Zob. G. Vattimo, Społeczeństwo przejrzyste, op. cit., s. 63.

${ }^{34}$ Zob. R. Przybylski, Klasycyzm w epoce krytyki filozofii podmiotu, [w:] idem, To jest klasycyzm, Warszawa 1978, s. 179.

35 Zob. A. Faltyn, Hermeneutyka w polskich badaniach literackich: Maria Janion, Ryszard Przybylski, Michał Paweł Markowski, Warszawa 2014, s. 352-353. 
jest czynienie znaczenia klarownym, tylko „sprostanie sytuacji załamania się znaczeń (...). Będąc hermeneutyką drżenia, działa w sytuacji, gdy drży wszystko"36 - czyli kiedy rozpadają się posągi.

Sytuację owego załamania, zburzenia ideałów przez katastrofę, oddaje wiersz Herberta Do Apollina o puencie:

\author{
szukam posągu \\ zatopionego w młodości \\ pozostał tylko pusty cokół - \\ ślad dłoni szukający kształtu ${ }^{37}$.
}

Figura jest więc oddzielona od postumentu niczym podmiot od swej przeszłości i od wartości, a tak jak cokół zastępuje tu ułomną rzeźbę bóstwa u Rilkego, tak wezwanie z jej strony zostaje zastąpione „szukaniem kształtu”, trafną metaforą postawy hermeneutycznej. Pisząc o mitach u autora Pana Cogito, Łukasiewicz rozważa, czy „zamieść te antyczne szczątki”, czy lepić z nich rozbite posągi, lub może „wystarczy wyobrazić sobie (...) posągi bogów i herosów, (...) pozwolić im w ten sposób zmartwychwstawać"38. Sam wybiera ostatnią opcję, współgrającą z pojęciem „monumentów” - przekazów naszych poprzedników, które domagają się pamięci ${ }^{39}$. Jednak na upamiętnianiu nie sposób poprzestać, lekceważąc „lepienie” posagów, owo „szukanie kształtu”, którego świadectwem są odpryski dawnych figur.

I nie poprzestaje poezja. W Alei w głębi czasu Kazimierz Wierzyński eksploruje strumień „upływu”, w którym jawi się

${ }^{36}$ B. Baran, Fenomenologia amerykańska. Studium z pogranicza, Kraków 1990, s. 162.

37 Z. Herbert, Do Apollina, [w:] idem, Poezje, Warszawa 1998, s. 24.

38 J. Łukasiewicz, op. cit., s. 124.

39 ,[M]onumentalność dzieła nie wynika więc $\mathrm{z}$ faktu, że obecna jest $\mathrm{w}$ nim prawda - prawda nie jest pełną obecnością tego, o kim pamięć dzieło wyraża, to raczej pamięć, która się ostała, czyni dzieło monumentalnym” - N. Leśniewski, op. cit., s. 75. 
Bez twarzy, bez rąk i bez szat,

Sama nagość w kamieniu,

Sama nagość miłości

Nie zatraconej w czasie,

Nie roztopionej w przyrodzie $(\ldots)^{40}$

Miłość „kująca w marmurach” pseudonimuje sensotwórczy wysiłek, który opiera się entropii.

Podobnie w Odysie u bogini Kalipso Romana Brandstaettera wyznanie: „U moich stóp leży czas / Jak pęknięty tors / Greckiego boga bez rąk" ${ }^{1}$ świadczy nie o chełpliwości, lecz o zgodzie na stawianie czoła ułomnościom ludzkiego losu oraz czasowi pękniętemu - pozbawionemu ciągłości i immanentnego sensu, który trzeba mu dopiero nadawać. Odyseusz z Wyspy syren tegoż poety tłumaczy, że nie mógł zalepić uszu na śpiew syren, gdyż w owym śpiewie trwa. Stawia jednak fundamentalne pytanie: „Śpiewasz we mnie / Czy poza mną?”, innymi słowy: czy sens jest obiektywny, czy też twórczo ustanawiany. Bohater ma świadomość, że obcuje ze szczątkami i porusza się w chaosie, lecz mimo spodziewanego fiaska nie ustaje w wysiłku łagodzenia tego, co Przybylski nazwał „demuzykalizacją świata”42: „Zdążam od klęski do klęski - / Stroiciel roztrzaskanych fortepianów"43.

Czy wobec tego hermeneutyka radykalna nie okazuje się oazą melancholii? Istotnie, Vattimo twierdzi, że do bycia można się przybliżać jedynie za pomocą „długiego pożegnania”, czyli przemyśliwania jego historii, ale nie „wskrzeszania” go jako esencji ${ }^{44}$. Także rehabilitacja mitu (w znaczeniu narracji i struktury myśli) jest możliwa jako wyraz (po)nowoczesnego doświadczenia,

${ }^{40}$ K. Wierzyński, Aleja w głębi czasu, [w:] idem, Poezje, oprac. E. Cichla-Czarniawska, Lublin 1990, s. 365.

${ }^{41}$ R. Brandstaetter, Odys u bogini Kalipso, [w:] idem, Dwie muzy, Warszawa 1965, s. 50.

${ }^{42}$ Zob. R. Przybylski, Wprowadzenie. Klasycyzm a demuzykalizacja świata, [w:] idem, To jest klasycyzm, op. cit., s. 15.

${ }^{43}$ R. Brandstaetter, Wyspa syren, [w:] idem, Dwie muzy, op. cit., s. 51.

${ }^{44}$ Zob. G. Vattimo, Poza interpretacja, op. cit., s. 23. 
w którym zamiast pewności cogito pozostają ,proustowskie zatrzymanie serca, medialne opowieści, mitologie zaświadczane przez psychoanalizę"45. Mimo nuty melancholii owa hermeneutyka nie optuje za patetycznym ocalaniem czy przywracaniem Sensu (konotującym fundamentalistyczną metafizykę), lecz sprzeciwia się pochłonięciu bycia (resp. mitów) przez bezsens:

\begin{abstract}
stara się utrzymać to, co sensowne, „z uwagi na” upływ (...). Utrzymać możliwość mówienia o sensie (...) z uwagi na zagrożenie utratą (...) odniesienia przedmiotowego, w którym to (...) przedmiot (...) staje się, jest więc rozumiany jako możliwość ${ }^{46}$.
\end{abstract}

W tym świetle wyłania się drugie dno słów Bocheńskiego, wskazującego na „u-topikę” topiki antycznej, która „niby jest, ale brak jej swojego gruntu"47, gdyż mity przestały być żywe. Brak gruntu można jednak potraktować jako szansę, tak jak John Caputo upatruje motywacji do utrzymywania sensu w „bezgruncie” i procesualności bycia ${ }^{48}$. Dzięki swemu niezakorzenieniu mity mogą być ciągle podejmowanym przesłaniem, a ich „powtarzanie” (w znaczeniu Kierkegaarda ${ }^{49}$ można rozpatrywać jako przywoływanie mitów w ich dynamice i kruchości, ale właśnie dlatego nieustannie wzywających do wysiłku rozumienia.

\title{
Bibliografia
}

Baran B., Fenomenologia amerykańska. Studium z pogranicza, Kraków 1990. Barańczak S., Uciekinier z Utopii. O poezji Zbigniewa Herberta, Warszawa 2001. Bocheński J., Przywitanie konferencji, [w:] Topika antyczna w literaturze polskiej XX wieku. Studia, red. A. Brodzka, E. Sarnowska-Temeriusz, Wrocław 1992. Brandstaetter R., Odys u bogini Kalipso; Wyspa syren, [w:] idem, Dwie muzy, Warszawa 1965.

${ }^{45}$ G. Vattimo, Społeczeństwo przejrzyste, op. cit., s. 54.

${ }^{46}$ N. Leśniewski, op. cit., s. 162.

47 Zob. J. Bocheński, op. cit., s. 11-12.

${ }^{48}$ Zob. Z. Dziuban, Obcość, bezdomność, utrata. Wymiary atopii wspótczesnego doświadczenia kulturowego, Poznań 2009, s. 90.

${ }^{49}$ Zob. J. Caputo, op. cit., s. 12. 
Bryll E., Rekonstrukcja chóru Sofoklesowego, [w:] idem, Wiersze wybrane, Kraków 1978.

Brzozowski J., Antyk Herberta, [w:] Topika antyczna w literaturze polskiej XX wieku. Studia, red. A. Brodzka, E. Sarnowska-Temeriusz, Wrocław 1992.

Caputo J., Radical Hermeneutics. Repetition, Deconstruction and the Hermeneutic Project, Bloomington-Indianapolis 1987.

Czerniawski A., U schyłku XX wieku, [w:] idem, Poezje zebrane, Łódź 1993.

Dziuban Z., Obcość, bezdomność, utrata. Wymiary atopii współczesnego doświadczenia kulturowego, Poznań 2009.

Faltyn A., Hermeneutyka w polskich badaniach literackich: Maria Janion, Ryszard Przybylski, Michat Pawet Markowski, Warszawa 2014.

Fluks P., Sukces, [w:] Po Wojaczku. Antologia poezji polskiej 1971-1991, red. K. Ratyniecki, Warszawa 1991.

Herbert Z., Do Apollina, [w:] idem, Poezje, Warszawa 1998.

Kamieńska A., Archeologia, [w:] eadem, Poezje wybrane, Warszawa 1973.

Leśniewski N., O hermeneutyce radykalnej, Poznań 1998.

Łukasiewicz J., Herbert, Wrocław 2001.

Mikołajczak M., „W cieniu heksametru”. Interpretacje wierszy Zbigniewa Herberta, Zielona Góra 2004.

Mit i współczucie, „Tygodnik Powszechny” 2008, nr 22.

Mizerkiewicz T., Mitologizacje. O zwiazkach intertekstualnych z mitologia w powieści polskiej po 1956 roku, „Pamiętnik Literacki” 2000, z. 4.

Przyboś J., Zapiski bez daty, Warszawa 1970.

Przybylski R., To jest klasycyzm, Warszawa 1978.

Stabryła S., Antyk we wspótczesnej literaturze polskiej, Wrocław 1980.

Szulakiewicz M., Filozofia jako hermeneutyka, Toruń 2004.

Szulakiewicz M., Od transcendentalizmu do hermeneutyki, Rzeszów 1998.

Vattimo G., Dialektyka, różnica, myśl słaba, przeł. M. Surma, A. Zawadzki, „Teksty Drugie" 2003, nr 5.

Vattimo G., Nihilizm i postmodernizm w filozofii, [w:] idem, Koniec nowoczesności, przeł. M. Surma-Gawłowska, Kraków 2006.

Vattimo G., Postnowoczesność i kres historii, przeł. B. Stelmaszczyk, [w:] Postmodernizm. Antologia przekładów, wybór i oprac. R. Nycz, Kraków 1997.

Vattimo G., Poza interpretacja. Znaczenie hermeneutyki dla filozofii, red. A. Kuczyńska, przeł. K. Kasia, Kraków 2011.

Vattimo G., Społeczeństwo przejrzyste, przeł. M. Kamińska, Wrocław 2006.

Vattimo G., Paterlini P., Nie być Bogiem. Autobiografia na cztery rece, przeł. K. Kasia, Warszawa 2011.

Wat A., Biografia, [w:] idem, Wybór wierszy, oprac. A. Dziadek, Wrocław 2008.

Wierzyński K., Aleja w głębi czasu, [w:] idem, Poezje, oprac. E. Cichla-Czarniawska, Lublin 1990.

Wróblewski M., Zatarg Jeana-Françoisa Lyotarda, czyli o postmodernizmie raz jeszcze, „Diametros” 2010, nr 24.

Zawadzki A., Literatura a myśl słaba, Kraków 2009. 